\title{
Kemampuan Literasi Matematis Siswa melalui Model Pembelajaran Problem Based Instruction
}

\author{
Vika Conie Fatwa ${ }^{*}$, Ari Septian² dan Sarah inayah ${ }^{3}$ \\ ${ }^{1 * 2,3}$ Program Studi Pendidikan matematika, Universitas Suryakancana \\ Jalan Dr. Muwardi Komplek Pasir Gede Raya, Cianjur, Jawa Barat, Indonesia \\ 1*vikaconie@gmail.com,2ariseptian@unsur.ac.id,3inayahsarah@unsur.ac.id
}

Artikel diterima: 03-07-2019, direvisi: 22-09-2019, diterbitkan: 30-09-2019

\begin{abstract}
Abstrak
Latar belakang penelitian ini yaitu masih rendahnya kemampuan literasi matematis. Penelitian ini bertujuan mengetahui apakah model pembelajaran Problem Based Instruction (PBI) yang juga sebagai alternatif solusi permasalahan dapat meningkatkan kemampuan literasi matematis siswa. Metode penelitian adalah kuasi eksperimen dengan desain Nonequivalent group pretestpostest design. Instrumen berbentuk tes literasi matematis berupa tes awal (pretest) dan tes akhir (posttest). Populasi penelitian ini adalah seluruh siswa kelas VIII SMP Negeri 5 Cianjur tahun ajaran 2018/2019 yang tersebar dalam sembilan kelas, sedangkan sampelnya dipilih dengan teknik purposive sampling sebanyak dua kelas yaitu kelas VIII D sebanyak 27 siswa sebagai kelas eksperimen yang diberikan perlakuan dengan menggunakan model pembelajaran Problem Based Learning (PBI), dan VIII C sebanyak 25 siswa sebagai kelas control dengan pembelajaran biasa. Berdasarkan penelitian diketahui bahwa terdapat peningkatan kemampuan literasi matematis siswa dengan model pembelajaran Problem Based Instruction (PBI). Peningkatan tersebut lebih baik jika dibandingkan dengan peningkatan pada siswa dengan pembelajaran biasa.

Kata Kunci: Kemampuan Literasi Matematis, Problem Based Instruction, PBI.
\end{abstract}

\section{Mathematical Literacy Ability Students through Problem Based Instruction Learning Models}

\begin{abstract}
The background of this research is low mathematical literacy ability. The purpose of this research is to find out the differences in increasing students' mathematical literacy ability between those who use the Problem Based Instruction (PBI) learning model as an alternative solution to the problem and who use ordinary learning. A method in this research is quasi-experimental with nonequivalent group pretest-posttest design. The instruments are a mathematical literacy instrument consisting of the initial test (pretest) and the final test (posttest). The population in this study were all students at SMP Negeri 5 Cianjur in year 2018/2019 that spread into 9th grade, while the samples chosen with purposive sampling technique were two classes, namely VIII $D$ class as the experimental class which is given Problem Based Learning (PBI) and VIII C as the control class with ordinary learning. Based on the tests of mathematical literacy abilities that have been analyzed it is found that there are differences in mathematical literacy skills students who applied the Problem Based Instruction (PBI) learning model is were better than ordinary learning. The increase is better when compared to the increase in students with ordinary learning. Keywords: Mathematical literacy ability, Problem Based Instruction, PBI.
\end{abstract}




\section{Pendahuluan}

Pendidikan secara umum dapat dikatakan sebagai segala upaya yang direncanakan untuk mempengaruhi manusia yang bermula dari ketidaktahuan, berubah menjadi berpengetahuan melalui belajar sehingga terjadinya perubahan mental (Skiner dalam Dimyati \& Mudjiono, 2006). Proses pembelajaran akan menghasilkan manusia yang berkualitas sehingga dapat mencapai tujuan pendidikan yang diharapkan.

Tujuan pendidikan merupakan indikator berhasilnya penyelenggaraan pendidikan. Oleh karena itu, sebagai acuan keberhasilan penyelenggaraan pendidikan, pemerintah Indonesia telah merumuskan tujuan pendidikan nasional yang tercantum dalam Undang-Undang Nomor 20 tahun 2003 tentang Sistem Pendidikan Nasional (UndangUndang Republik Indonesia, 2003).

Upaya dalam mencapai tujuan pendidikan di Indonesia terus ditingkatkan agar dapat menjadi bangsa yang maju. Perkembangan zaman ditandai oleh berkembangnya teknologi, semakin luasnya informasi dan komunikasi yang semakin pesat. Salah satu bidang yang memberikan pengaruh besar terhadap kemajuan teknologi adalah matematika. Saat ini teknologi berkembang dengan tidak pernah luput dari peranan matematika. Oleh karena itu, matematika adalah termasuk ilmu yang penting dalam kehidupan dan sebagai ilmu dasar yang wajib manusia khususnya siswa dalam rangka untuk mempersiapkan diri dalam menghadapi perkembangan zaman.

Hal ini sejalan dengan (Mulyani, Wahyuningsih, \& Natalliasari, 2019) guna mengatasi berbagai permasalahan dan kesulitan dampak dari perkembangan zaman tersebut diperlukan suatu kemampuan dan kegigihan menghadapi berbagai rintangan dengan terus belajar dan semangat untuk terus mengembangkan diri.

Peranan matematika bermanfaat bagi kehidupan. Adapun tujuan pembelajaran matematika di Indonesia menekankan pada dimensi pedagogik modern dalam pembelajaran, yaitu menggunakan pendekatan scientific (ilmiah). Kegiatan yang dilakukan agar pembelajaran bermakna yaitu mengamati, menanya, mencoba, menalar, menyaji, dan mencipta (Kemdikbud, 2015).

Apabila dicermati, dalam tujuan pembelajaran matematika, terlihat bahwa kurikulum yang disusun sudah menunjukkan aspek pengembangan literasi matematis yaitu merumuskan, menggunakan dan menafsirkan matematika dalam berbagai konteks (Afriansyah \& Putri, 2014) untuk kehidupan sehari-hari.

Sedangkan, pada pembelajaran matematika di Indonesia saat ini masalah yang berkaitan dengan kehidupan sehari-hari hanya digunakan sebagai sumber inspirasi penemuan atau pembentukan konsep dikarenakan kurangnya kemampuan literasi siswa sehingga siswa hanya mengaplikasikan konsep yang sudah ada bukan mengkaji dan menafsirkan sendiri konsep matematika (Warmi, 2019; Jeheman, Gunur, \& Jelatu, 2019).

Literasi matematis didefinisikan sebagai kemampuan seseorang individu merumuskan, menggunakan dan menafsirkan matematika dalam berbagai konteks, termasuk kemampuan melakukan penalaran secara matematis dan menggunakan konsep, prosedur, fakta, sebagai alat untuk mendeskripsikan, menerangkan dan memprediksi suatu fenomena atau kejadian (Zyngier dkk., 2013). Hal ini berarti, literasi matematis dapat membantu individu untuk mengenal peran matematika di dunia nyata 
dan sebagai dasar pertimbangan dan penentuan keputusan yang dibutuhkan oleh masyarakat.

Pengertian ini mengisyaratkan literasi matematis sangatlah penting bagi siswa supaya memahami matematika tidak hanya pada penguasaan materi saja akan tetapi hingga kepada penggunaan penalaran, konsep, fakta dan alat matematika dalam pemecahan masalah sehari-hari serta menuntut peserta didik untuk mengkomunikasikan dan menjelaskan fenomena yang dihadapinya dengan konsep matematika.

Akan tetapi kemampuan literasi matematis siswa Indonesia masih rendah. Hal ini terlihat berdasarkan dari hasil survey PISA (Programme for International Student Assessment) tahun 2015 dalam bidang matematika menunjukkan bahwa Indonesia berada di peringkat 62 dari 72 negara. Walaupun pada tahun 2015 Indonesia mengalami peningkatan dibandingkan dengan tahun 2012. Berdasarkan nilai rata-rata, dalam kompetensi matematika pada tahun 2012 sebesar 375 poin telah meningkat menjadi 386 poin di tahun 2015. Tetapi jika dilihat dari peringkat tetap saja Indonesia masih rendah dalam kompetensi matematika khususnya dalam kemampuan literasi matematis (PISA, 2016).

Selain itu, hasil kajian beberapa penelitian sebelumnya mengkaji pentingnya kemampuan literasi matematis siswa untuk dikaji, yaitu: 1) Analisis mahasiswa calon guru (Prabawati, 2018); 2) Pengembangan soal matematika realistic (Mangelep \& Kaunang, 2018); 3) Konsep operasi bilangan pecahan (Suwarto, 2018); dan 4) Pengembangan LKS berbasis masalah (Prabawati, Herman, \& Turmudi, 2019).
Kenyataan lapangan menunjukkan bahwa kemampuan literasi matematis belum dilatih secara maksimal dan soal-soal yang mengukur kemampuan literasi siswa juga belum tersedia. Terdapat beberapa sumber kendala yang dihadapi para guru dalam menilai literasi matematis, yaitu: kurangnya pengetahuan guru tentang kompetensi literasi matematis dan belum ada format penilaian literasi matematis.

Berbagai macam upaya telah dilakukan oleh berbagai pihak terutama guru-guru dalam mengajar matematika guna membekali siswa agar memiliki kemampuan berpikir logis, analitis, sistematis, kritis, dan kreatif serta kemampuan untuk bekerja sama (Prabawati, 2018). Upaya-upaya yang dilakukan bisa dengan menerapkan dan mengembangkan model, pendekatan maupun strategi pembelajaran matematika yang karakteristiknya dapat meningkatkan kemampuan literasi matematis siswa.

Kemampuan literasi untuk siswa di Indonesia masih rendah. Oleh karena itu, perlu ditingkatkan. Untuk meningkatkan kemampuan literasi matematis diperlukan pembelajaran yang melibatkan siswa dalam suatu pemecahan masalah sebagai dasar pertimbangan dan penentuan keputusan berkaitan dengan matematika di dunia nyata melalui tahap-tahap metode ilmiah. Salah satu alternatif model pembelajaran yang dapat digunakan adalah Model Pembelajaran Problem Based Instruction (PBI).

Model Pembelajaran Problem Based Instruction (PBI) adalah suatu metode pengajaran dengan pendekatan pembelajaran siswa pada masalah autentik ( Nadz \& Haq, 2013). PBI merupakan model pembelajaran yang menyajikan suatu kondisi belajar siswa aktif serta melibatkan siswa dalam suatu 
pemecahan masalah melalui tahap-tahap metode ilmiah. PBI ini diharapkan dapat memfasiltasi siswa untuk mempelajari pengetahuan yang berhubungan dengan masalah yang disajikan serta dapat memiliki suatu keterampilan dalam memecahkan masalah.

Model pembelajaran ini juga sesuai dengan kurikulum yang digunakan saat ini yaitu Kurikulum 2013. Model pembelajaran ini menghadapkan siswa pada suatu masalah yang sering ditemukan siswa dalam kehiduan sehari-hari (Nadz \& Haq, 2013). Dalam kurikulum saat ini, siswa harus aktif berinteraksi dengan guru maupun siswa lain, sehingga pembelajaran tidak berfokus pada guru tetapi siswa juga berperan aktif dalam pembelajaran (Vusparatih, 2014).

Selain dapat meningkatkan kemampuan literasi matematis, dalam PBI juga terdapat ciri khusus yaitu adanya kerjasama antar siswa. Dalam hal ini kerjasama akan mendorong siswa untuk mengembangkan kemampuan berpikir melalui tukar pendapat serta berbagai penemuan yang berhasil ditemukan bersama. Selain itu kerjasama juga dapat membantu siswa dalam mengembangkan motivasi pada diri masing-masing siswa (Al-Tabany, 2014).

Berdasarkan uraian yang telah dikemukakan, penelitian ini bertujuan untuk mengetahui perbedaan peningkatan kemampuan literasi matematis siswa yang mendapatkan pembelajaran dengan model pembelajaran Problem Based Instruction (PBI) lebih baik dibandingkan siswa yang memperoleh pembelajaran biasa.

\section{Metode}

Metode penelitian ini yaitu penelitian eksperimen. Menurut (Sugiyono, 2016), kuasi eksperimen dilakukan tanpa mengontrol semua variabel dan subjek tidak dipilih secara random

(non

random

sampling).

Pembelajaran dengan menggunakan Model Pembelajaran Problem Based Instruction (PBI) sebagai variabel bebas yang akan mempengaruhi variabel terikatnya yaitu kemampuan literasi matematis. Pada penelitian ini ada dua kelompok sebagai subjek penelitian, yaitu eksperimen dan kontrol. Kelompok eksperimen yaitu kelas yang menerapkan model Problem Based Instruction (PBI), sedangkan kelompok kontrolnya adalah kelas yang mendapatkan pembelajaran biasa. Desain penelitian yang dilakukan adalah Nonequivalent Group pretest-postest Design.

Subjeknya adalah siswa kelas VIII dipilih sebanyak 2 kelas yaitu kelas VIII D untuk kelas eksperimen dan kelas VIII C sebagai kelas kontrol. Pemilihan kelas sebagai sampel dipilih secara purpossive sampling. Siswa kelas eksperimen sebanyak 27 orang dan siswa kelas kontrol sebanyak 25 orang.

Untuk mengukur peningkatan kemampuan literasi matematis siswa, instrumen yang digunakan dalam penelitian ini berupa tes. Instrumen jenis tes adalah instrumen literasi matematis berupa tes awal (pretest) dan tes akhir (posttest) sebanyak 4 soal uraian dengan indikator kemampuan literasi matematis yaitu merumuskan masalah secara matematis, menggunakan konsep, fakta, prosedur dan penalaran dalam matematika, dan menafsirkan matematika untuk memecahkan masalah.

Instrumen terlebih dahulu dilakukan uji validitas untuk mengetahui apakah soal-soal tersebut dapat dipahami dengan baik atau tidak dan reliabilitas. Uji coba instrumen diberikan kepada siswa yang telah mendapatkan materi pelajaran untuk mengetahui validitas butir soal dan reliabilitas tes. 
Menurut (Arikunto, 2013), validitas adalah suatu ukuran yang menunjukkan tingkattingkat kesahihan suatu instrumen. Validitas tes untuk menunjukkan tingkat kevalidan atau kesahihan instrumen yang telah dibuat. Dalam penelitian ini untuk menganalisis validitas instrumen digunakan program Anates.

Klasifikasi untuk menginterpretasikan hasil validitas butir soal disajikan dalam tabel 1 berikut. Hasil analisis uji validitas diperoleh tiap butir soal pada table 2 sebagai berikut.

Berdasarkan tabel 2 diperoleh bahwa dari empat soal yang diujikan, satu soal mempunyai validitas tinggi, dan tiga soal mempunyai validitas sangat tinggi.

Analisis reliabilitas digunakan untuk alat ukur suatu instrumen. Instrumen tersebut harus konsisten memberikan informasi yang sesuai dengan kenyataan dan dengan materi sehingga instrumen dapat dikatakan reliabel.

Berdasarkan hasil perhitungan dengan menggunakan bantuan program Anates diperoleh nilai koefisien reliabilitas tes sebesar 0,91 . Nilai ini menunjukkan bahwa reliabilitas instrumen yang digunakan tergolong ke dalam kategori derajat reliabilitas sangat tinggi.

Tabel 1

Klasifikasi Validitas Instrumen

\begin{tabular}{cc|}
\hline Nilai & Interpretasi Validitas \\
\hline $0,80 \leq r_{x y} \leq 1,00$ & Validitas Sangat Tinggi \\
\hline $0,60 \leq r_{x y}<0,80$ & Validitas Tinggi \\
\hline $0,40 \leq r_{x y}<0,60$ & Validitas Sedang \\
\hline $0,20 \leq r_{x y}<0,40$ & Validitas Rendah \\
\hline$r_{x y}<0,20$ & Validitas Sangat Rendah \\
\hline
\end{tabular}

Tabel 2

Hasil Validitas Instrumen

\begin{tabular}{cccc}
\hline $\begin{array}{c}\text { No } \\
\text { Soal }\end{array}$ & (rxy) & Klasifikasi Validitas & Keterangan \\
\hline 1 & 0,771 & Tinggi & Soal digunakan \\
\hline 2 & 0,876 & Sangat Tinggi & Soal digunakan \\
\hline 3 & 0,912 & Sangat Tinggi & Soal digunakan \\
\hline 4 & 0,924 & Sangat Tinggi & Soal digunakan \\
\hline
\end{tabular}

Artinya Instrumen layak untuk dijadikan soal tes.

Materi yang diujikan dalam penelitian ini adalah materi bangun ruang sisi datar dengan sub materi bangun kubus dan balok.

Prosedur penelitian ini terdiri dari empat tahap, yaitu: a) tahap persiapan penelitian yaitu menyusun proposal penelitian, pembuatan instrumen penelitian, menganalisis hasil validasi, melakukan uji coba soal, mengajukan perizinan penelitian, serta pemilihan kelompok ekperimen dan kelompok kontrol, b) tahap pelaksanaan penelitian yaitu memberikan pretest, melaksanakan pembelajaran sesuai dengan rencana kegiatan pembelajaran dan memberikan posttest, c) tahap pengolahan data yaitu mengolah dan menganalisis hasil data kuantitatif yang diperoleh dari pretest dan posttest, serta skala sikap siswa menggunakan bantuan software SPSS versi 24 , d) tahap penarikan kesimpulan yaitu menarik kesimpulan dengan menjawab rumusan masalah dan memberikan saran.

\section{Hasil dan Pembahasan}

\section{A. Hasil Penelitian}

\section{Analisis Data Pretest}

Pada tabel 3 dapat menjelaskan bahwa rata-rata skor kelas eksperimen lebih tinggi dari rata-rata kelas kontrol, perbedaan rataratanya sebesar 3,55, skor minimum kelas eksperimen lebih rendah dari kelas kontrol, berbedannya sebesar 3, sedangkan skor maksimum kelas eksperimen dan kelas kontrol

Tabel 3.

Deskripsi Statistik Skor Pretest

\begin{tabular}{|ccc|}
\hline Kelas & Eksperimen & Kontrol \\
\hline $\mathrm{N}$ & 27 & 25 \\
\hline Rata-rata & 26,07 & 22,52 \\
\hline Std. Deviation & 9,294 & 5,245 \\
\hline Minimum & 15 & 18 \\
\hline Maximum & 47 & 35
\end{tabular}


perbedaannya sebesar 12 dengan kelas eksperimen yang lebih tinggi skornya. Selain itu standar deviasi untuk kelas eksperimen kelas kontrol memiliki perbedaan 4,049.

Untuk mengetahui apakah kemampuan literasi matematis siswa terdapat kesamaan atau perbedaan secara signifikan, maka dilakukan uji statistik lainnya.

\section{a. Uji Normalitas Data Pretest}

Berdasarkan tabel 4, hasil uji normalitas dengan menggunakan uji Kolmogorov-Smirov menyatakan bahwa nilai signifikansi kedua kelas menunjukkan kurang dari 0,05, maka menurut kriteria pengujian $\mathrm{H}_{0}$ ditolak. Sehingga dapat disimpulkan bahwa kedua kelas berasal dari populasi yang tidak berdistribusi normal, maka pengujian dilanjutkan dengan uji non parameterik MannWhitney.

\section{b. Uji Mann-Whitney Data Pretest}

Berdasarkan tabel 5, diperoleh hasil uji Mann-Whitney yaitu nilai Asymp Sig. (2-tailed) lebih besar dari 0,05, maka menurut kriteria pengujian $\mathrm{H}_{0}$ diterima. Artinya, kedua kelas memiliki nilai pretest yang sama. Sehingga

Tabel 4.

Hasil Uji Normalitas Skor Pretest

\begin{tabular}{ccc}
\hline Kelas & Eksperimen & Kontrol \\
\hline $\mathrm{N}$ & 27 & 25 \\
\hline Sig. & 0,002 & 0,000 \\
\hline Keterangan & Ho ditolak & Ho ditolak \\
\multicolumn{4}{c}{ Tabel 5. } \\
Hasil Uji Mann-Whitney (Pretest) \\
\hline Data Pretest & Asymp Sig-(2-tailed) & Ket \\
\hline Kelas & \multicolumn{3}{c}{ Ho } \\
eksperimen & 0,191 & diterima \\
\hline Kelas Kontrol & & \\
\hline
\end{tabular}

Tabel 6.

Deskripsi Statistik Skor Indeks Gain

\begin{tabular}{|ccc|}
\hline Kelas & Eksperimen & Kontrol \\
\hline $\mathbf{N}$ & 27 & 25 \\
\hline Rata-rata & 0,7022 & 0,3120 \\
\hline Std. Deviation & 0,25767 & 0,14130 \\
\hline Minimum & 0,21 & 0,07 \\
\hline Maximum & 1,00 & 0,54 \\
\hline
\end{tabular}

dapat diambil kesimpulan skor pretest kemampuan awal literasi matematis sama.

\section{Analisis Data Indeks Gain}

Berdasarkan tabel 6, diperoleh informasi bahwa rata-rata indeks gain kelas eksperimen lebih tinggi daripada kelas kontrol dengan perbedaan rata-rata sebesar 0,9302. Selanjutnya untuk mengetahui seberapa besar perbedaan peningkatan kemampuan literasi matematis siswa dapat dilakukan dengan pengujian statistik. Terlebih dahulu akan dilakukan uji normalitas pada data indeks gain kelas eksperimen dan kelas kontrol.

\section{a. Uji Normalitas Data Indeks Gain}

Berdasarkan tabel 7, diperoleh hasil uji Kolmogorov-Smirov dengan nilai signifikansi kelas eksperimen menunjukkan nilai yang kurang dari 0,05, maka kriteria $\mathrm{H}_{0}$ ditolak sehingga data indeks gain kelas eksperimen tidak berdistribusi normal.

Sedangkan nilai signifikansi kelas kontrol menunjukkan nilai lebih dari 0,05, maka menurut kriteria pengujian $\mathrm{H}_{0}$ diterima, sehingga data indeks gain kelas kontrol berdistribusi normal Dilakukan dengan uji non-parametrik dengan menggunakan uji Mann-Whitney karena salah satu sampel dari populasi yang tidak berdistribusi normal.

b. Uji Mann-Whitney Data Indeks Gain

Pada pengujian sebelumnya, data indeks gain kelas eksperimen tidak memenuhi asumsi kenormalan, maka langkah selanjutnya yaitu uji non-parametrik Mann-Whitney. Uji dilakukan untuk mengetahui peningkatan kemampuan literasi matematis siswa yang memperoleh pembelajaran dengan menggunakan model Problem Based

Tabel 7.

Hasil Uji Normalitas Skor Indeks Gain

\begin{tabular}{|ccc|}
\hline Kelas & Eksperimen & Kontrol \\
\hline $\mathrm{N}$ & 27 & 25 \\
\hline Sig. & 0,040 & $\mathrm{H}_{0}$ ditolak \\
\hline Keterangan & 0,200 & Ho diterima
\end{tabular}


Instruction (PBI) lebih baik daripada siswa yang memperoleh pembelajaran biasa.

Berdasarkan tabel 8 , Nilai sig $(1$-tailed $)=1 / 2$ sig $(2$-tailed $)$ berarti sig(1-tailed $)=1 / 2(0,000)=$ 0,000 sehingga Asymp. Sig. (1-tailed) sebesar 0,000 kurang dari 0,05 maka $\mathrm{H}_{0}$ ditolak dan $\mathrm{H}_{1}$ diterima. Berarti dapat disimpulkan bahwa peningkatan kemampuan literasi matematis siswa yang memperoleh pembelajaran menggunakan model Problem Based Instruction (PBI) lebih baik daripada kemampuan literasi dengan siswa yang memperoleh pembelajaran biasa.

Berdasarkan rata-rata indeks gain diperoleh nilai rata-rata indeks gain kelas eksperimen yaitu 0,28 , lebih tinggi daripada nilai rata-rata indeks gain kelas kontrol yaitu 0,09. Berarti dapat disimpulkan bahwa peningkatan kemampuan literasi matematis siswa yang mengikuti pembelajaran menggunakan model Problem Based Instruction (PBI) lebih baik daripada siswa yang mengikuti pembelajaran biasa.

\section{B. Pembahasan}

Berdasarkan hasil pengolahan tes awal (Pretest) pada kelas eksperimen dan kelas kontrol didapatkan bahwa nilai rata-rata kelas eksprimen lebih tinggi dibandingan dengan kelas kontrol. Akan tetapi dari hasil pengujian hipotesis dengan uji non parametrik MannWhitney, diperoleh bahwa tidak terdapat perbedaan kemampuan awal literasi matematis antara siswa kelas kontrol dan siswa kelas eksperimen. Karena kedua kelas mempunyai kemampuan yang sama,

Tabel 8.

Hasil Uji Mann-Whitney (Indeks Gain)

Data Indeks Gain Kelas Kelas Kontrol
Eksperimen

\begin{tabular}{cc|}
\hline Asump Sig-(2-tailed) & 0,000 \\
\hline Asymp Sig-(1-tailed) & 0,000 \\
\hline Ket & Ho ditolak
\end{tabular}

Mosharafa: Jumal Pendidikan Matematika

Volume 8, Nomor 3, September 2019

Copyright $\odot 2019$ Mosharafa: Jurnal Pendidikan Matematika kemudian dilakukan proses penelitian yaitu dengan memulai proses pembelajaran di kelas eksperimen dan di kelas kontrol, kelas eksperimen menggunakan model pembelajaran Problem Based Instruction (PBI) sedangkan kelas kontrol dengan menggunakan pembelajaran biasa, tetapi kedua kelas diberikan materi yang sama yaitu kubus dan balok.

Dari hasil uji statistik data n-gain, menunjukkan bahwa pembelajaran dengan model Problem Based Instruction (PBI) dapat dipilih sebagai alternatif model pembelajaran di kelas untuk meningkatkan kemampuan literasi matematis siswa pada materi kubus dan balok.

Adapun faktor penyebab perbedaan signifikan antara peningkatan kemampuan literasi matematis siswa yang mendapat pembelajaran dengan model Problem Based Instruction (PBI) dengan siswa yang mendapat pembelajaran biasa yaitu : 1) Guru menyediakan pengalaman belajar yang dirancang pada model Problem Based Instruction (PBI), selain itu diskusi kelompok/ berpasangan disertai LKK yang membantu siswa dalam memahami materi. 2) Pada kelas eksperimen pembelajaran dilakukan dengan menggunakan model Problem Based Instruction (PBI) dimana siswa lebih banyak terlibat aktif dalam menemukan rumus-rumus yang ada pada pembelajaran, sehingga akan berpengaruh pada kemampuan literasi matematis siswa dalam mengaitkan siswa kepada bidang ilmu matematika lain, maupun dunia nyata. 3) Pada proses pembelajaran seluruh siswa dibuat menjadi berkelompok, hal ini mengakibatkan siswa lebih mampu mengapresiasi pengetahuan yang siswa miliki serta hubungan antar teman sekelas terutama dalam hal saling tukar menukar ide berjalan 
dengan lancar. Sedangkan kelas kontrol pembelajaran dilakukan seperti biasa, walaupun hampir sama dengan eksperimen tetapi kelas kontrol hanya berdiskusi dalam menyelesaikan masalah (mengerjakan soal) yang ada pada suatu pembelajaran.

Model pembelajaran Problem Based Instruction (PBI) juga tidak hanya lebih baik dibandingkan pembelajaran biasa akan tetapi lebih baik juga ketika dibandingkan dengan model pembelajaran konvensional, dan tidak hanya dalam kemampuan literasi matematis siswa tetapi juga dalam kemampuan penalaran matematis siswa. Hal ini berdasarkan hasil penelitian yang dilakukan oleh (Nadz. 2013).

\section{Penutup}

Berdasarkan hasil analisis dan pembahasan, diperoleh kesimpulan yaitu perbedaan peningkatan kemampuan literasi matematis siswa yang memperoleh model pembelajaran Problem Based Instruction (PBI) lebih baik daripada peningkatan kemampuan literasi matematis siswa yang memperoleh pembelajaran biasa.

Adapun saran yang direkomendasikan dari hasil penelitian dan kesimpulan mengenai model pembelajaran Problem Based Instruction (PBI) ini yaitu 1) model pembelajaran Problem Based Instruction (PBI) dapat digunakan sebagai strategi pembelajaran matematika, pada kelas yang memiliki kemampuan literasi matematis yang sama dengan siswa kelas VIII di SMP Negeri 5 Cianjur, 2) model pembelajaran Problem Based Instruction (PBI) memerlukan kemampuan guru menciptakan suasana kondusif pada proses pembelajaran, 3) penelitian model pembelajaran Problem Based Instruction (PBI) ini disarankan untuk dilanjutkan dengan subjek penelitian yang lebih luas, misal SMA, SMK, maupun perguruan tinggi, dan 4) penelitian kemampuan literasi matematis ini disarankan untuk subjek penelitian yang lebih luas, misal SMA, SMK, maupun Perguruan Tinggi.

\section{UCAPAN TERIMA KASIH}

Terima kasih penulis ucapkan kepada pihak sekolah yang telah mengizinkan penulis untuk melakukan penelitian.

\section{DAFTAR PUSTAKA}

Afriansyah, E. A., \& Putri, R. I. I. (2014). Design Research: Konsep Nilai Tempat Pada Operasi Penjumlahan Bilangan Desimal Di Kelas V Sekolah Dasar. Jurnal Pendidikan Matematika, 8(1), 13-24.

Al-Tabany, T. I. B. (2014). Mendesain Model Pembelajaran Inovatif, Progresif, dan Kontekstual. In PRENADAMEDIA GROUP.

Dimyati, \& Mudjiono. (2006). Hakikat Belajar dan Pembelajaran. Belajar Dan Pembelajaran, 9.

Jeheman, A. A., Gunur, B., \& Jelatu, s. (2019). Pengaruh Pendekatan Matematika Realistik terhadap Pemahaman Konsep Matematika Siswa. Mosharafa: Jurnal Pendidikan Matematika, 8(2). 191-202. DOI: https://doi.org/10.31980/mosharafa .v8i2.454

Kemdikbud. (2015). Materi Pelatihan guru Implementasi Kurikulum. Materi Pelatihan Guru Implementasi Kurikulum 2013, (Jakarta, PSDMPK-PMP 2015), 2015.

Mangelep, N. O., \& Kaunang, D. F. (2018). Pengembangan Soal Matematika Realistik Berdasarkan Kerangka Teori Program for International Students Assessment. Mosharafa: Jurnal Pendidikan Matematika, 7(3), 455-466. DOI:

https://doi.org/10.31980/mosharafa.v7i3 .157

Mulyani, E., Wahyuningsih, S., \& Natalliasari, I. (2019). Adversity Quotient Mahasiswa 
Pendidikan Matematika dan Keterkaitannya dengan Indeks Prestasi Kumulatif. Mosharafa: Jurnal Pendidikan Matematika, 8(1), 119-130. DOI: https://doi.org/10.31980/mosharafa.v8i1 .418

Nadz, T. F., \& Haq, C. N. (2013). Pembelajaran Melalui Metode Problem Based Instruction (PBI) dengan Metode Konvensional. Mosharafa: Jurnal Pendidikan Matematika, 2(3), 191-202.

PISA. (2016). PISA 2015 Results in Focus. In OECD.

https://doi.org/10.1787/9789264266490 -en

Prabawati, M. N. (2018). Analisis Kemampuan Literasi Matematik Mahasiswa Calon Guru Matematika. Mosharafa: Jurnal Pendidikan Matematika, 7(1), 113-120. DOI:

https://doi.org/10.31980/mosharafa.v7i1 .347

Prabawati, M. N., Herman, T., \& Turmudi, T. (2019). Pengembangan Lembar Kerja Siswa Berbasis Masalah dengan Strategi Heuristic untuk Meningkatkan Kemampuan Literasi Matematis. Mosharafa: Jurnal Pendidikan Matematika, 8(1), 37-48. DOI: https://doi.org/10.31980/mosharafa.v8i1 .383

Sugiyono. (2016). Metode Penelitian Kuantitatif, Kualitatif dan Kombinasi (Mixed Methods). Bandung: Alfabeta, 2016.

Suwarto, S. (2018). Konsep Operasi Bilangan Pecahan melalui Garis Bilangan. Mosharafa: Jurnal Pendidikan Matematika, 7(3), 327-336. DOI: https://doi.org/10.31980/mosharafa.v7i3 .73

Undang-Undang Republik Indonesia. (2003). Nomor 20 Tahun 2003. Tentang Sistem Pendidikan Nasional, (1), 1-26.

Vusparatih, D. S. (2014). Peranan Komunikasi Guru dalam Implementasi Kurikulum 2013. Humaniora, 5(1), 387. https://doi.org/10.21512/humaniora.v5i1 .3037

Warmi, A. (2019). Pemahaman Konsep Matematis Siswa Kelas VIII pada Materi Lingkaran. Mosharafa: Jurnal Pendidikan Matematika, 8(2). 297-306. DOI: https://doi.org/10.31980/mosharafa .v8i2.384

Zyngier, D., Zullig, K. J., Collins, R., Ghani, N., Hunter, A. A., Patton, J. M., ... 김성식. (2013). PISA 2012 results : ready to learn. Students' engagement, drive and selfbeliefs (volume III). School Effectiveness and School Improvement, 24(2), 520 pages.

https://doi.org/10.1080/09243453.2012. 680892

\section{Riwayat Hidup PenUlis Vika Conie Fatwa, S.Pd.}

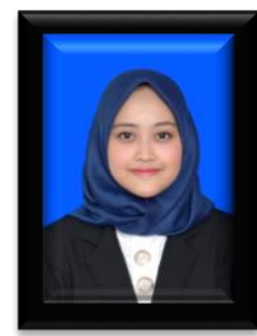

Lahir di Cianjur pada tanggal 16 Februari $1997 . \quad$ Penulis merupakan anak pertama dari 3 bersaudara. Saat ini penulis beralamat di Kp. Ciranji Wetan. No 92. Rt 001/004 Ds. Sirnagalih Kec. Cilaku Kab. Cianjur, Jawa Barat. Studi S1 di Universitas Suryakancana Cianjur sebagai mahasiswa Fakultas Keguruan dan IImu Pendidikan (FKIP) Program Studi pendidikan Matematika.

\section{Ari Septian, S.Si., M.Pd.}

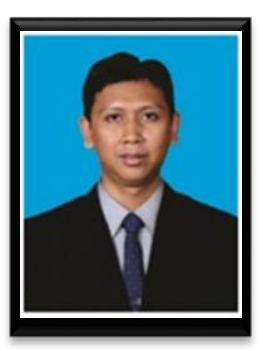

Lahir di Cianjur pada tanggal 12 September 1985. Penulis adalah dosen sekaligus ketua Program Studi Pendidikan Matematika, Fakultas Keguruan dan Ilmu Pendidikan Universitas Suryakancana. Studi S1 bidang matematika di Institut Pertanian Bogor, lulus pada tahun 2008. Studi S2 bidang pendidikan matematika di Universitas Pasundan, lulus pada tahu 2012. Sekarang sedang melanjutkan studi S3 bidang pendidikan matematika di Universitas Pendidikan Indonesia. 
Sarah Inayah, S.Pd., M.Pd.

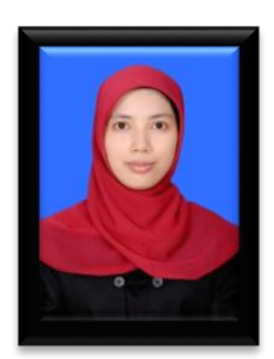

Lahir di Cianjur, 15 Februari 1988. Penulis adalah staf pengajar di program studi pendidikan matematika, Fakultas Keguruan dan IImu Pendidikan Universitas Suryakancana Cianjur. Studi S1 bidang pendidikan

matematika di Universitas Suryakancana Cianjur, tahun lulus 2010. Studi S2 bidang pendidikan matematika di Universitas Pendidikan Indonesia, Bandung, tahun lulus 2013. 